\title{
Resolving biogeochemical processes in lakes using remote sensing
}

\author{
Vincent Nouchi ${ }^{1,3}$ (1) Tiit Kutser ${ }^{2} \cdot$ Alfred Wüest $^{1,3} \cdot$ Beat Müller $^{3} \cdot$ Daniel Odermatt $^{3,4} \cdot$ Theo Baracchini $^{1}$. \\ Damien Bouffard ${ }^{3}$
}

Received: 7 June 2018 / Accepted: 24 January 2019

(c) Springer Nature Switzerland AG 2019

\begin{abstract}
Remote sensing helps foster our understanding of inland water processes allowing a synoptic view of water quality parameters. In the context of global monitoring of inland waters, we demonstrate the benefit of combining in-situ water analysis, hydrodynamic modelling and remote sensing for investigating biogeochemical processes. This methodology has the potential to be used at global scales. We take the example of four Landsat- 8 scenes acquired by the OLI sensor and MODIS-Aqua imagery over Lake Geneva (France-Switzerland) from spring to early summer 2014. Remotely sensed data suggest a strong temporal and spatial variability during this period. We show that combining the complementary spatial, spectral and temporal resolutions of these sensors allows for a comprehensive characterization of estuarine, littoral and pelagic nearsurface features. Moreover, by combining in-situ measurements, biogeochemical analysis and hydrodynamic modelling with remote sensing data, we can link these features to river intrusion and calcite precipitation processes, which regularly occur in late spring or early summer. In this context, we propose a procedure that can be used to monitor whiting events in temperate lakes worldwide.
\end{abstract}

Keywords Landsat-8 $\cdot$ MODIS-Aqua $\cdot$ Inland waters $\cdot$ Remote sensing $\cdot$ Calcification $\cdot$ Whiting $\cdot$ Global scale monitoring $\cdot$ In-situ measurements

\section{Introduction}

Lake remote sensing was hampered for many years by the absence of appropriate satellite sensors (Palmer et al. 2015). Yet, land remote sensing sensors were used for inland water studies (Brezonik et al. 2005; Kallio et al. 2008; Kutser 2012), but their radiometric resolution remained a severe limitation especially for oligo- to mesotrophic water bodies. Environmental Satellite with the Medium Resolution

Vincent Nouchi

vincent.nouchi@gmail.com

1 Physics of Aquatic Systems Laboratory, Margaretha Kamprad Chair, EPFL-ENAC-IEE-APHYS, 1015 Lausanne, Switzerland

2 Department of Remote Sensing and Marine Optics, Estonian Marine Institute University of Tartu, Mäealuse 14, 12618 Tallinn, Estonia

3 Eawag, Swiss Federal Institute of Aquatic Science and Technology, Surface Waters, Research and Management, Seestrasse 79, 6047 Kastanienbaum, Switzerland

4 Odermatt \& Brockmann GmbH, Stampfenbachstrasse 57, 8006 Zurich, Switzerland
Imaging Spectrometer (MERIS) was among the first suitable sensor for investigating large lakes at $300 \mathrm{~m}$ resolution, but it finished its operations in 2012. At the time, only the Moderate Resolution Imaging Spectroradiometer (MODIS) aboard the Aqua Spacecraft could partially substitute the observational capabilities, yet, with a coarser spatial resolution $(1 \mathrm{~km})$ and less bands in the near-infrared part of the spectrum compared to MERIS, but with nearly daily revisits. With a significantly better spatial resolution $(30 \mathrm{~m})$ than its precursors, Landsat-8 (launched in 2013) allowed for mapping water quality parameters (Kutser et al. 2016; Lee et al. 2016; Slonecker et al. 2016) yet at 16 days temporal resolution, and thus complementing MODIS' capabilities in the spatio-temporal domain. Since the launch of Sentinel-2A (2015) and 2B (2017), as well as Sentinel-3A (2016) and $3 \mathrm{~B}(2018)$ there is high $(10-60 \mathrm{~m})$ and medium resolution $(300 \mathrm{~m})$ imagery available with improved spectral resolution and 5 days and daily revisit intervals at higher latitudes and at the equator, respectively. The combined use of both sensor types is key for better resolving near surface aquatic processes in lakes at all temporal and spatial scales. 
The attempt to provide a unique remote sensing algorithm performing well over the wide variety of inland water is very challenging, if possible. In 1892, Forel already described lakes as unique environments: "Every lake is a geographical individual well separated from its congeners, in which physical and biological facts develop as in a world apart, independently of any relation with other lakes". This diversity was taken into account in the recent Copernicus Global Land Cover maps at $100 \mathrm{~m}$ resolution (C-GLOPS) project by clustering lakes into 13 different classes and applying different sets of algorithms for each of them (Spyrakos et al. 2018). However, there are often multiple ecological processes that may produce similar optical signatures (IOCCG 2000). We illustrate this difficulty with two examples. First, the vertical structure of the optically active substances which interact with the light (e.g. chlorophyll-a) has significant impact on the remote sensing signal (Bouffard et al. 2018; Nouchi et al. 2018; Pitarch et al. 2014). It has been also shown that vertical distribution of cyanobacteria, capable of moving in the water column, influences both the absolute values and the shape of the remote sensing signal (Kutser et al. 2008; Xue et al. 2015, 2017). Then, the high backscattering signal in a lake may result from elevated concentration of allochthonous particles brought to the lake by river inflows or autochthonous "whiting" (calcite precipitation) within the water column. Whiting typically occurs when calcium carbonate is oversaturated due to high $\mathrm{pH}$ and/or high calcium input (Wells and Illing 1964). The initiation of whiting requires impurities that act as nucleation cells for calcites which are often initiated by phytoplankton blooms (Obst et al. 2009) or river inflows (Spencer et al. 1985). It is quite common in peri-alpine lakes, where river water, often rich in fine glacial particles from mountainous catchments, plunges to deeper layers within tens to a few hundred meters from the river mouth after entering a lake (Finger et al. 2006). Most of the time, river flows intrude into the thermocline, where the river water finds its equilibrium with the lake water profile (Hauenstein and Dracos 1984; Råman Vinnå et al. 2017). In spring or early summer, the thermocline can be shallow and the lake water clear enough to allow riverine suspended solids trapped in the thermocline region to be detected from satellite sensors. The problem of detecting river particles intruding into lakes becomes even more challenging as the flow is often trapped near the shore at shallow depth. Therefore, parts of the signal detected by satellites may in fact reflect near-shore lake beds. As an example, it may be nearly impossible to separate sandy sediment in $1 \mathrm{~m}$ depth with clear water from water rich in mineral particles where transparency is $1 \mathrm{~m}$, especially when multispectral sensors are used (Kutser et al. 2006).

While new methods are being developed to account for the lake variability (in between lakes but also spatially and temporally in a specific lake), we show in this study that combining information sources is a very efficient way to interpret remote sensing signals of lake processes. Lakes have been historically monitored with in-situ measurements (Anneville and Pelletier 2000; Gallina et al. 2013) and more recently with hydrodynamic models (Bouffard et al. 2018; Soulignac et al. 2018). Local and remotely sensed observations are typically used to calibrate and validate numerical models (Matthews 2011; Odermatt et al. 2012). Here, we show that the combination of in-situ, model data and remote sensing products can be used, not only for calibration/validation purposes but also to ultimately provide a system-based understanding of remotely sensed maps.

Lake Geneva is a particularly interesting waterbody from a remote sensing perspective. Most of the year the surface water is clear. Phytoplankton blooms occur close to the surface in late spring (Anneville et al. 2002a; Kiefer et al. 2015) and progressively move into deeper waters during the productive season becoming undetectable by remote sensing except when basin-scale internal waves move the thermocline upward into the photic zone (Bouffard et al. 2018; Bouffard and Lemmin 2013). Phytoplankton growth-seasonrelated whiting events are known to occur in parts of Lake Geneva (Plée et al. 2010). Whether phytoplankton blooms or suspended matter initiate them is however still unknown.

During productive seasons, the duration of algal blooms, whiting and major inflows is such that these events are often missed by conventional monitoring of the lake at bi-monthly intervals. For these cases, remote sensing can make a major contribution in understanding these processes assuming it is possible to recognize the biogeochemical processes.

This study was triggered by a striking event of lake waters turning from clear blue to opaque turquoise in June 2014. This event received wide attention by the public which frames its time of occurrence quite accurately. An article was published in local newspapers on June 18, 2014 (https:// www.lematin.ch/suisse/Pourquoi-les-eaux-du-Leman-sontturquoises/story/13801189) with the event itself starting probably 1 or 2 days earlier. We used low-resolution MODIS and high-resolution Landsat- 8 imagery in combination with in-situ data and a hydrodynamic model to investigate this particular event.

\section{Study site and methods}

\section{Lake Geneva}

Lake Geneva is the largest lake in Western Europe $\left(580 \mathrm{~km}^{2}\right)$ divided between Switzerland and France (Fig. 1). The Rhône is the main tributary of the lake accounting for $68 \%$ of the total water inflow (Burkard 1984). Minor rivers are Venoge and Aubonne in the north flowing down from the Jura Mountains and the Dranse in the south originating in the 
Fig. 1 Overview map of Lake Geneva. The two sampling stations in the lake (SHL2) and in the Rhône (Porte-du-Scex, PS) are indicated

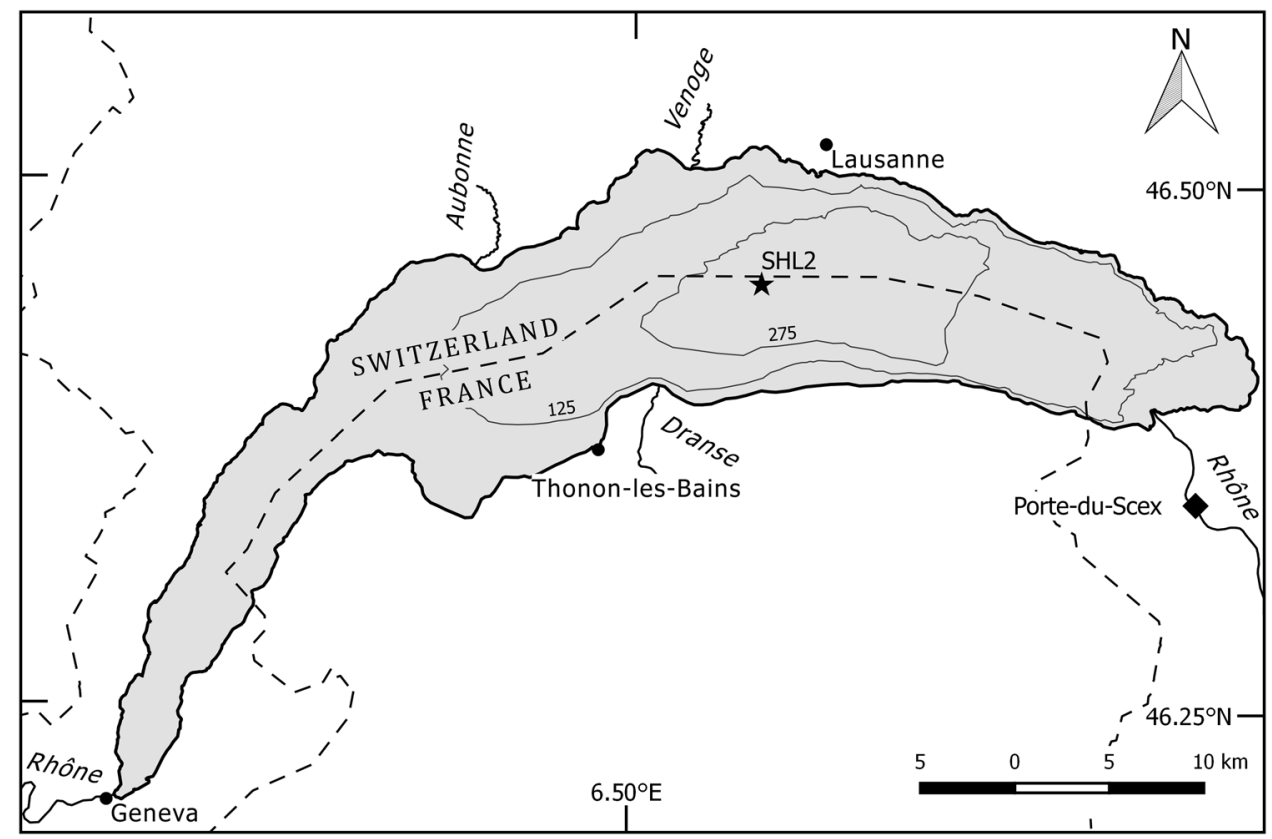

Alps. The Rhône, transporting mineral-rich glacier water, is the main source of particulate material flushed into the lake. Its water is all year round colder than the surface lake water and plunges to deeper layers of the lake (thermocline or below) very close to the river mouth not allowing riverine particles to spread at the surface.

The socio-economic and ecological relevance of the lake for the region conciliated the French and Swiss Governments to sign a convention in 1963 to protect and preserve its waters. This convention, triggered by eutrophication, formalized the effort to continuously monitor the lake and its watershed at key stations and promoted measures to reduce the nutrient loads to the lake which initiated its slow recovery (Anneville et al. 2002a). In this study, we used bio-physico-chemical datasets from two stations: in Lake Geneva at SHL2 (Fig. 1) and from the Rhône River at Porte-du-Scex (PS, Fig. 1). The lake monitoring data were provided by the Commission Internationale pour la Protection des Eaux du Léman (CIPEL) which has monitored the lake since 1957 at monthly to fortnightly intervals depending on the season. In the river, PS data were provided by the Swiss Federal Office of the Environment (FOEN), partly measured at the high frequency of $10 \mathrm{~min}$.

\section{Satellite data and processing}

\section{MODIS-Aqua}

Lake Geneva is covered by MODIS tile h18v4 with a spatial resolution of $\sim 1 \mathrm{~km}$ for bands relevant to water observations. The MODIS-Aqua level $1 \mathrm{~A}$ (raw radiances) data from 1 to 30 June 2014 were obtained from the US Goddard
Space Flight Center (https://oceancolor.gsfc.nasa.gov) at the National Aeronautics and Space Administration and processed on the Calvalus Earth observation data processing cluster of the European Space Agency. We used SeaDAS v 7.412 gen to produce calibrated at-sensor radiance and top of the atmosphere reflectance from L1A products, and to flag land pixels. The top of the atmosphere reflectance values greater than 0.25 (dimensionless) were considered as cloud pixels and, like the land pixels, they were removed from the analysis. Further processing involved the Case-2 Regional Coast Colour (C2RCC) processor applied using National Centers for Environmental Prediction v0.18 auxiliary data for atmospheric correction and retrieval of inherent optical properties and water constituents. C2RCC is a neural network algorithm based on the approach by Doerffer and Schiller (2007) which allows the retrieval of optically active components using a large database of radiative transfer simulations (Brockmann et al. 2016). In this study we used the Chlorophyll-a (CHL) and the total suspended matter (TSM) products as qualitative information on the spatial distribution of phytoplankton patches and inorganic particle plumes. An accurate quantification is not required for this purpose. It was however shown with a predecessor of the C2RCC processor and MERIS data that such neural network algorithms are more appropriate for oligo- to mesotrophic lakes than e.g. ocean colour band ratios (Odermatt et al. 2010, 2012).

\section{Landsat-8}

There are two Landsat- 8 orbits that cover most of Lake Geneva: the 28th row of both path numbers 195 and 196. This means that the imagery is available with double 
frequency compared to the 16 days revisit interval. Landsat-8 imagery, showing elevated water leaving signal (bright patches) in some parts of the lake was available for June 8 and 15, 2014 during the prominent event. Cloud-free images before and after the event where available on May 23, and July 17, 2014. Atmospheric correction, for the estimation of the water-leaving reflectance ( $\rho_{\mathrm{w}}$, dimensionless), was performed using the Short-wave infrared correction of the Atmospheric Correction for OLI 'lite' (ACOLITE) (Vanhellemont and Ruddick 2014, 2015, 2016) with fixed aerosol type $(\varepsilon=1)$, and a smoothing window of $330 \mathrm{~m}$. Input Level-1 radiance was adjusted using the spectral gains suggested by Pahlevan et al. (2014). Water constituent retrieval with Landsat- 8 was also performed, but atmospherically corrected and contrast enhanced true-colour imagery in combination with quantitative estimates from MODIS were found to be more informative, in particular concerning OLI's limitations for CHL retrieval in oligo- to mesotrophic waters (Odermatt et al. 2012).

\section{In-situ dataset}

Physico-chemical measurements used in this study were obtained during standardized monthly monitoring measurements by UMR CARRTEL INRA at Thonon-les-Bains (Unité Mixte de Recherche entre l'INRA et l'Université de Savoie; Centre Alpin de Recherche sur les Réseaux Trophiques des Ecosystèmes Limniques) on behalf of CIPEL. Sampling at station SHL2 is carried out at 20 depth: $0 ; 2.5 ; 5 ; 7.5 ; 10 ; 15 ; 20 ; 25 ; 30 ; 35 ; 50 ; 100 ; 150 ; 200 ; 250$; 275; 290; 300; 305 and $309 \mathrm{~m}$. Detailed reporting and quality assessment is provided in yearly publications by CIPEL (http://www.cipel.org/le-leman/rapport-scientifique/). All water samples are analysed for CHL using the Strickland and Parsons (1968) method. Concentrations of calcium $\left(\mathrm{Ca}^{2+}\right)$ are determined analytically by ion chromatography and alkalinity is measured by acid titration $(0.01 \mathrm{M} \mathrm{HCl})$ to the inflection point. Lake water $\mathrm{pH}$ was measured immediately after sampling while the $\mathrm{pH}$ of the Rhône water at PS is available at 10 min intervals. Water sampling at PS (Fig. 1) was accomplished in the frame of the NADUF program (National Long-term Surveillance of Swiss Rivers, http:// www.eawag.ch/en/department/wut/main-focus/chemistryof-water-resources/naduf/) where samples were collected proportional to water discharge. Water sampling at PS follows the same analytical procedure as CIPEL with additional measurements of TSM using the gravimetric method. In parallel to water sampling, Conductivity, Temperature and Depth (CTD) sensor measurements were performed within the entire water column in the lake at SHL2 (Blanc et al. 1993) and at a single depth in the river at PS (Fig. 1), while the transparency was recorded at both stations using a Secchi disk. Sampling and analysis of Lake Geneva site SHL2 water is conducted at a minimum of monthly intervals and we used data from April 7, June 2, and June 30, 2014 accessed through the Information System of the SOERE OLA-IS () (http://si-ola.inra.fr) on May 19, 2017. Discharge, pH, temperature and conductivity data were provided between 2011 and 2017 at $10 \mathrm{~min}$ intervals while concentrations of TSM and $\mathrm{Ca}^{2+}$ were provided at fortnightly intervals for the same time period (https://www.bafu.admin.ch).

\section{River intrusion model}

Whiting events share similar features as river plumes which also bring mineral particles into the lake. While both sources will consistently increase the general amplitude of the reflectance in the whole spectral domain, calcite particles scatter the light more efficiently (Balch et al. 1989; Bricaud and Morel 1986), resulting in relatively higher reflectance. In this section, we describe the mechanism of the river intrusion in order to comprehend its observability from a remote sensing perspective. Figure 2 illustrates the processes in Lake Geneva beyond the Rhône River inflow. It has been shown that the maximum distance from the shore to the plunging point of the river flow (Hauenstein and Dracos
Fig. 2 Sketch showing the main processes during the intrusion of the Rhône waters (1) in the lake (2): entrainment of lake waters into the Rhône plume (3) and detrainment of particles from the Rhône water into the surface layer of the lake (4)

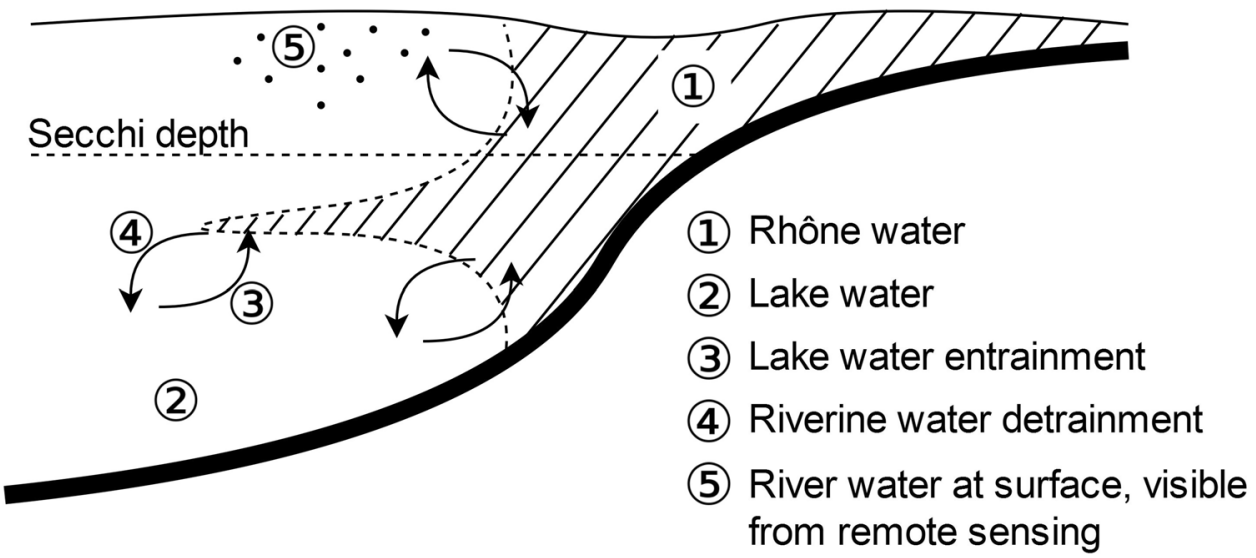


1984) is about $100 \pm 20 \mathrm{~m}$ quite independently of the Rhône inflow, as the river mouth topography is very steep (Sastre et al. 2010).

The maximum depth, where the river waters intrude into the lake waters depends on the density difference between the water masses. A small part of mineral particles can stay in the surface layer as a marginal overflow due to detrainment during the plunge phase and the amount of such particles is larger when the density difference (depending mainly on temperature difference) is smaller (i.e. in winter and early spring). Therefore, seeing small amounts of river plumes in spring is realistic, but it is unlikely in summer. Yet, the inflowing water can be at a shallower depth than the maximum depth of light penetration and thereby being detectable by remote sensing sensors. Consequently, a first estimate of the river intrusion depth is needed to correctly interpret the images from satellites.

The river intrusion depth was calculated according to the model previously developed for Lake Geneva and thoroughly described in Råman Vinnå et al. (2018) from density difference calculation and lake water entrainment. To feed the river intrusion model, river and lake water density were calculated using the Chen and Millero (1986) formulas for temperature and salinity (measured via conductivity) and the density increment caused by the inorganic river particles at PS was added.

\section{Hydrodynamic model}

The Delft3D-FLOW hydrodynamic simulation software has been selected for this study. It is an open-source hydrodynamic modelling suite solving a coupled system of differential equations for momentum, heat, mass and salinity driven by atmospheric forcing. Delft3D-FLOW has been successfully applied to Lake Geneva (Bouffard et al. 2018; Soulignac et al. 2018).

Given the steep lake morphologies, the z-layers scheme (100 vertical layers with thickness gradually increasing from the surface to the bottom) is used to reproduce the vertical stratification. The horizontal grid resolution was set to $500 \mathrm{~m}$ and we used the $\kappa-\varepsilon$ turbulence closure model. A time-step of $1 \mathrm{~min}$ is defined to maintain model stability. As initial conditions, the lake is initialized (uniformly horizontally) from an in-situ profile taken at the deepest point of the lake in January.

In terms of atmospheric forcing, MeteoSwiss COSMO2 reanalysis products (https://www.meteoswiss.admin.ch/ home/measurement-and-forecasting-systems/warningand-forecasting-systems/cosmo-forecasting-system/cosmo -1-high-resolution-forecasts-for-the-alpine-region.html) consisting of seven meteorological variables on a regular $2.2 \mathrm{~km}$ grid with an hourly resolution are used. Those variables include solar radiations, wind direction and intensity, relative humidity, cloud cover, pressure, and air temperature from their weather model tailored to the Alpine region with data assimilation.

\section{Calculation of the calcite saturation}

The concentration of the species $\left[\mathrm{Ca}^{2+}\right]$ was calculated from the analytically determined total $\mathrm{Ca}$ concentrations, $[\mathrm{Ca}]_{\text {tot }}$, considering the dissolved Ca complexes given in Eq. (1):

$\left[\mathrm{Ca}^{2+}\right]=[\mathrm{Ca}]_{\mathrm{tot}}-\left(\left[\mathrm{CaOH}^{+}\right]+\left[\mathrm{CaHCO}_{3}^{+}\right]+\left[\mathrm{CaCO}_{3}\right]_{\mathrm{aq}}\right)$

Concentrations of the components of the carbonate system $\left(\mathrm{pCO}_{2}, \mathrm{H}_{2} \mathrm{CO}_{3}{ }^{*}, \mathrm{HCO}_{3}{ }^{-}, \mathrm{CO}_{3}{ }^{2-}\right)$ were calculated from the measurements of alkalinity and $\mathrm{pH}$ as described in Stumm and Morgan (1996). Chemical equilibrium constants applied were adjusted to the measured temperatures using the relationships suggested by Plummer and Busenberg (1982).

The saturation index $\Omega$, for calcite was calculated as the ratio of the activity product of $\left\{\mathrm{Ca}^{2+}\right\}$ and $\left\{\mathrm{CO}_{3}{ }^{2-}\right\}$ and the temperature-corrected solubility constant, $K_{s_{0}}$ :

$\Omega=\frac{\left\{\mathrm{Ca}^{2+}\right\}\left\{\mathrm{CO}_{3}^{2-}\right\}}{K_{s_{0}}}$

Chemical activities were calculated with the DebyeHückel approximation (Stumm and Morgan 1996) and the ionic strength from the concentrations of major anions and cations which are available from the CIPEL monitoring at SHL2 (CIPEL 2015).

\section{Results and discussion}

\section{Low resolution imaging spectrometry}

Given the short temporal scale of the observed event, we first investigate daily MODIS CHL and TSM products for all of June 2014. Baseline conditions in the beginning of the month corresponded to the nutrient depletion phase after the spring bloom. TSM concentrations were below $2 \mathrm{~g} \mathrm{~m}^{-3}$, CHL concentrations were around $1 \mathrm{mg} \mathrm{m}^{-3}$, with short-term slightly elevated values of $2-3 \mathrm{mg} \mathrm{m}^{-3}$ occurring on June 1, 6 and 8. On June 10, TSM in the eastern part of the lake increased up to $5 \mathrm{~g} \mathrm{~m}^{-3}$, while CHL patterns retrieved from the same data shows inverse spatial variability (Fig. 3). This direct retrieval result and the consistently low productivity on previous days suggest that the detected particles in the east are inorganic, and preventing growth of detectable algae. In other systems, massive blooms of cyanobacteria, coccolithophores or other highly scattering phytoplankton 
Fig. 3 Distribution of CHL (left) and TSM (right) from June 8 to 21, 2014. Each row corresponds to a different date. The background hillshade was computed from Shuttle Radar Topography Mission data (USGS 2006)

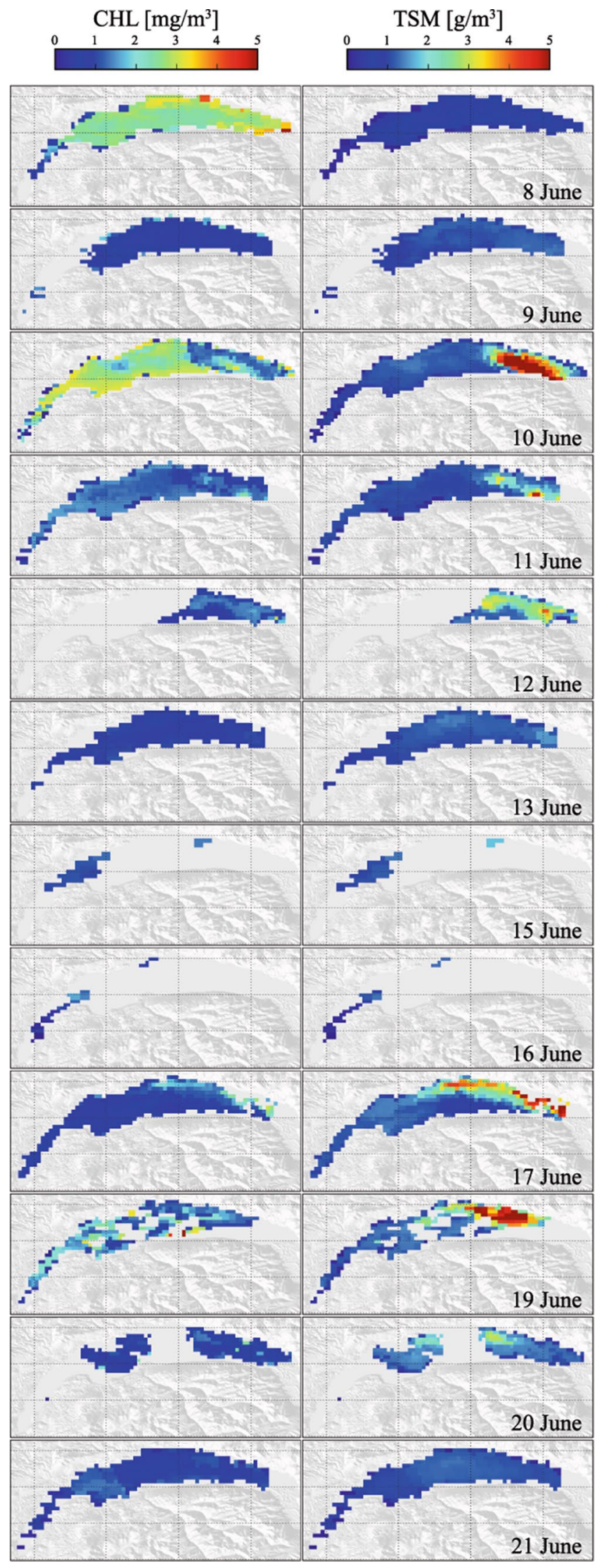


species could explain such pattern, but they do not occur in Lake Geneva (Anneville et al. 2002b). On the following days, the inorganic particle patch varies in density and develops from the southern shore, while CHL remains low and increases only occasionally and in coincidence with inorganic matter (Fig. 3). From June 21 onwards, the lake is back to background concentrations of $1-2 \mathrm{mg} \mathrm{m}^{-3} \mathrm{CHL}$ and $1-2 \mathrm{~g} \mathrm{~m}^{-3}$ TSM.

Next, we assess whether the inorganic particles extending between the Rhône mouth and the lake's centre are autochthonous calcite or allochthonous riverine particles.

The Rhône River typically intrudes in the thermocline or below (Giovanoli and Lambert 1985; Lambert and Giovanoli 1988; Loizeau and Dominik 2000). The spread of the riverine water is thereby typically below the expected vertical sampling depth of optical remote sensing (Nouchi et al. 2018). Furthermore, the spatial scale, sudden appearance and lack of dilution gradient evident in MODIS products support the hypothesis that the particles result from an internal lake process. Further verification of this hypothesis calls for complementary information sources, such as high resolution Landsat-8 imagery, hydrodynamic models and biogeochemical measurements.

\section{High resolution image interpretation}

On May 23, a Landsat-8 acquisition shows clear water conditions with locally increased turbidity near the Rhône River, small river inlets and near the shores (Fig. 4a). The Rhône inputs a median mineral particles load of $229 \mathrm{~g} \mathrm{~m}^{-3}$ between May 23 and July 17. Reflectance in the Rhône channel stands accordingly out due to its magnitude and red peak (Fig. 5), while the reflectance of riverine input from the Rhône and the Dranse decrease and shift towards shorter wavelength peaks as the plumes dilute with lake water within about 5 and $3 \mathrm{~km}$, respectively. The next acquisition on June 8 displays large, dark greenish areas along the shores of the Eastern basin (Fig. 4b), which coincides with the areas of increased CHL in the MODIS product. 1 week later the situation was strikingly different, when a $30 \mathrm{~km}$ long stretch with elevated reflectance at all visible wavelengths extends across the eastern part of the lake (Fig. 4c). On July 17 most of the lake is clear again (Fig. 4d). Note that small clouds (Fig. 4c, entire lake) and sun glint (Fig. 4c, western basin; Fig. 4d, Rhône estuary) are present in parts of the images. As far as small-scale circulation is concerned, Landsat-8 resolves also small-scale circulation patterns with blueish (P4 in Fig. 4b) and greenish (P3 in Fig. 4b) fronts. It is known from previous investigations that vertical non-uniformities in Lake Geneva are developing around this time of the year (Nouchi et al. 2018). In early June 2014, monitoring measurements from the lake centre indicate phytoplankton growth at about $\sim 2.5 \mathrm{~m}$ depth, while the turbidity maximum

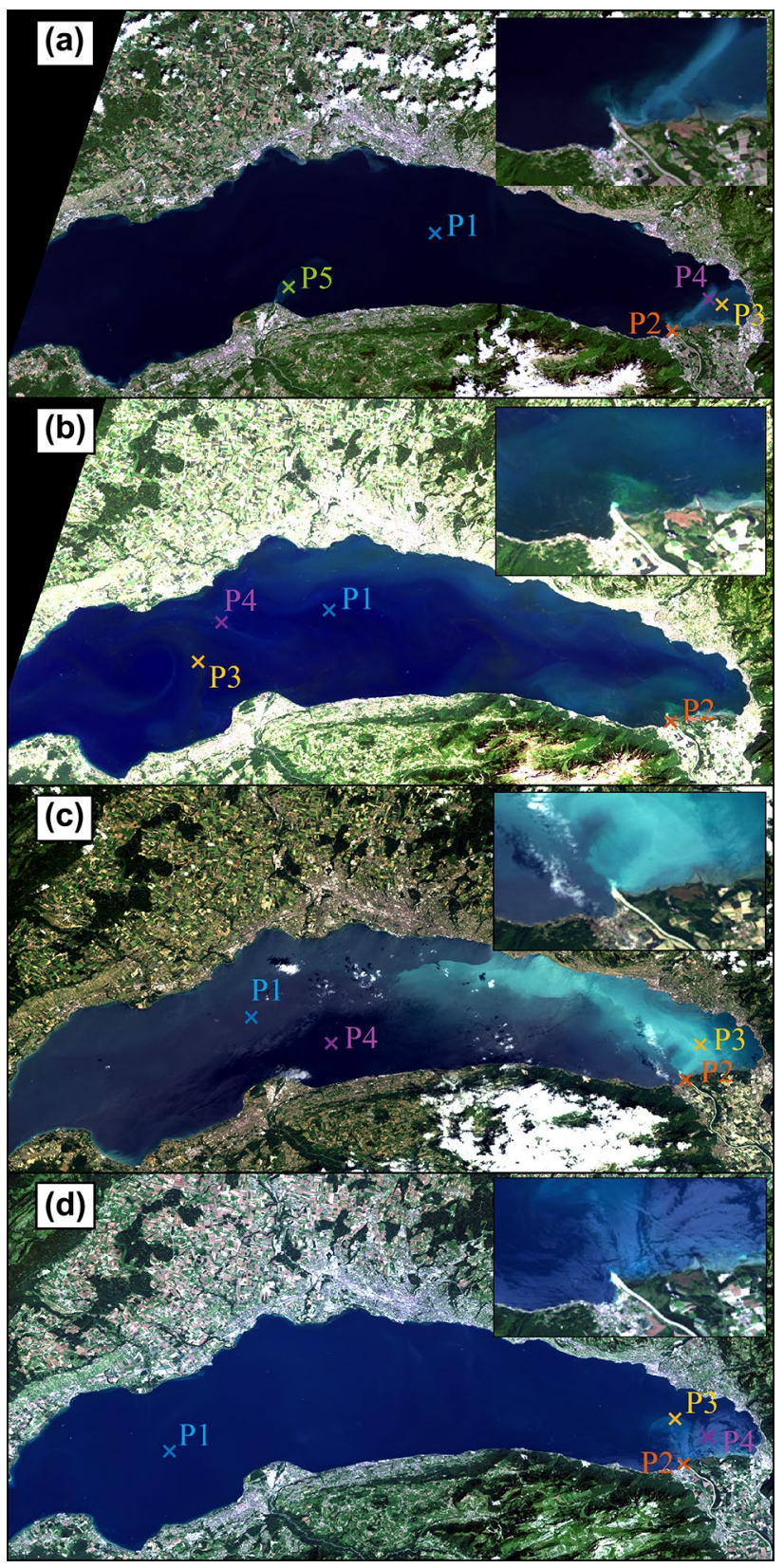

Fig. 4 Landsat-8 image of Lake Geneva from a May 23, b June 8, c June 15 , d July 17, 2014. The insets zoom (top right of each sub figure) show the Rhône inflow area. Crosses indicate the pixels where water reflectance spectra shown in Fig. 5 were collected

is at $7 \mathrm{~m}$ depth. This distribution can be associated with the variegated and rarely aligned circulation patterns observed on June 8 . These patterns are below the signal penetration depth of OLI's red band, where reflectance variations remain accordingly low (Fig. 5).

In contrast, we can identify in the image insets the Rhône's plunge points, which are defined as the location where the density-driven river water sinks to the thermocline and disappears from the surface. This distance is 

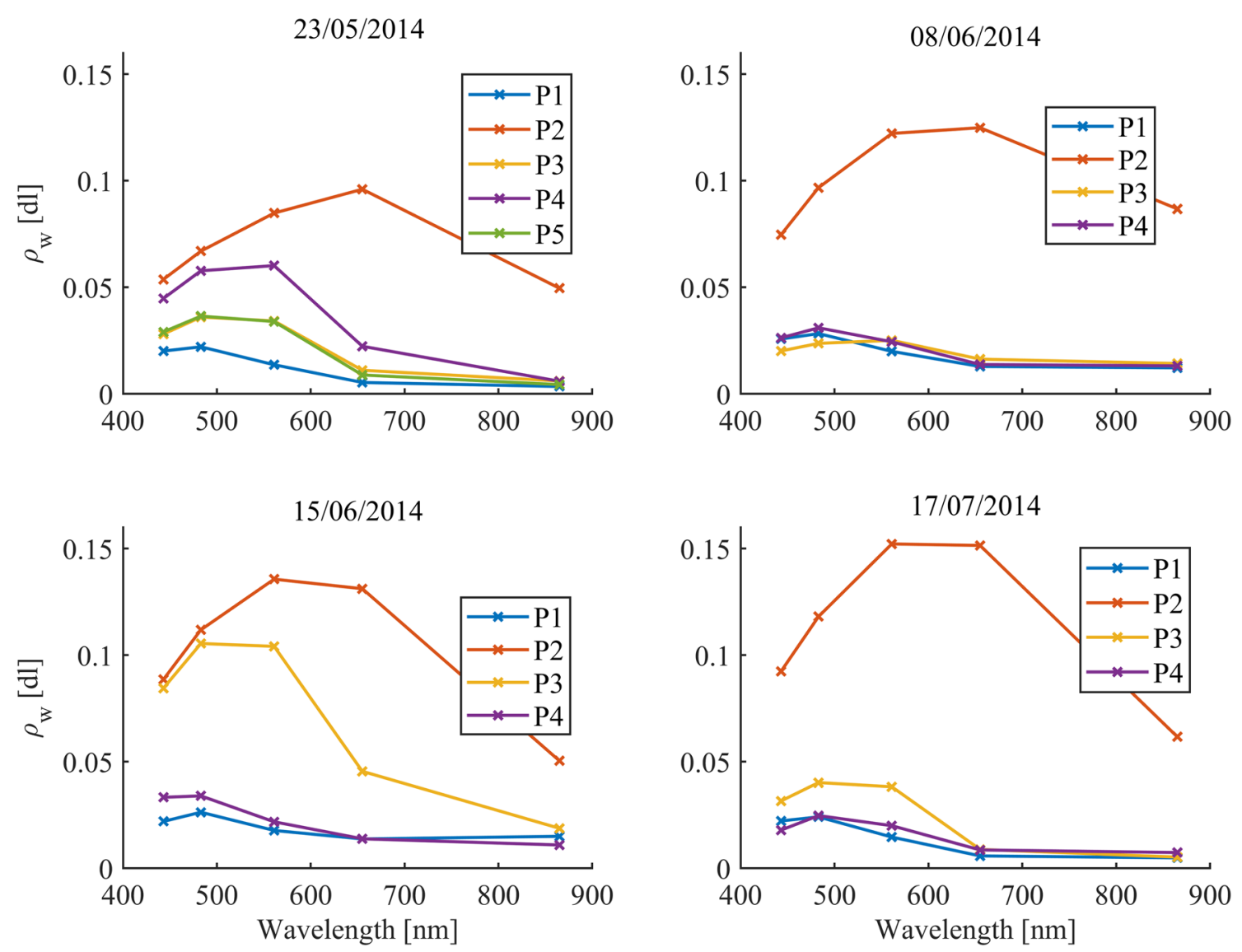

Fig. 5 Reflectance $\rho_{\mathrm{w}}$ collected from the four Landsat-8 images in Fig. 4. Exact locations P1-P5 of the extracted pixels are shown in Fig. 4; $\mathrm{dl}=$ dimensionless

$\sim 90 \pm 30 \mathrm{~m}$ for most of the year, even through times when the river discharge increases threefold. But in spring, differences between lake and river temperatures are relatively low (Lambert and Giovanoli 1988). In early June 2014, the $4 \mathrm{~km}$ long plumes of the Rhône and the Dranse inflows indicate that the condition were also favourable for a marginal overflow of riverine water close to the surface (Fig. 4a).

\section{Bio-geochemical profiles}

Spatial patterns of the greenish and whitish water masses do not co-vary at many places. This suggests that these two water masses are located at different depths. Indeed, the vertical profiles of CHL and turbidity measured a few days before (Fig. 6) show that the algal biomass maximum is at $\sim 2.5 \mathrm{~m}$ depth, whereas the turbidity maximum occurred at $7 \mathrm{~m}$ depth. We cannot identify the reason why there appears to be whitish water based on the reflectance spectra. The extent of such areas suggest that it was not riverine mineral particles from the Rhône or other smaller inflows and it was also not resuspension of particles in shallow nearshore areas

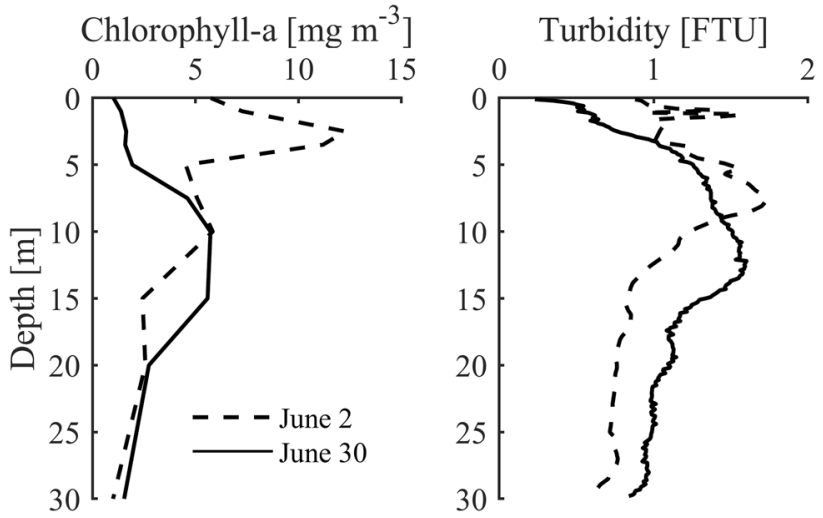

Fig. 6 CIPEL profiles at station SHL2 of CHL (left) and turbidity (right) for June 22014 (solid line) and June 30, 2014 (dashed line)

that exist only in some parts of the lake as narrow stripes. Therefore, the initiation of a whiting event is the most probable cause. 


\section{Model simulations}

The mighty plume covering half of Lake Geneva on June 15, 2014 starts right at the Rhône inflow point. The first assumption is that the plume resulted from a massive inflow event of mineral particles from the Rhône. We simulated the depth distribution of river intrusion based on the physical conditions (temperature, conductivity and particle content). Figure 7 shows that in spring, when the temperature difference between lake and river water is small, the typical intrusion depth is between 5 and $10 \mathrm{~m}$. In June the intrusion occurred mostly between 15 and $20 \mathrm{~m}$ depth. This intrusion

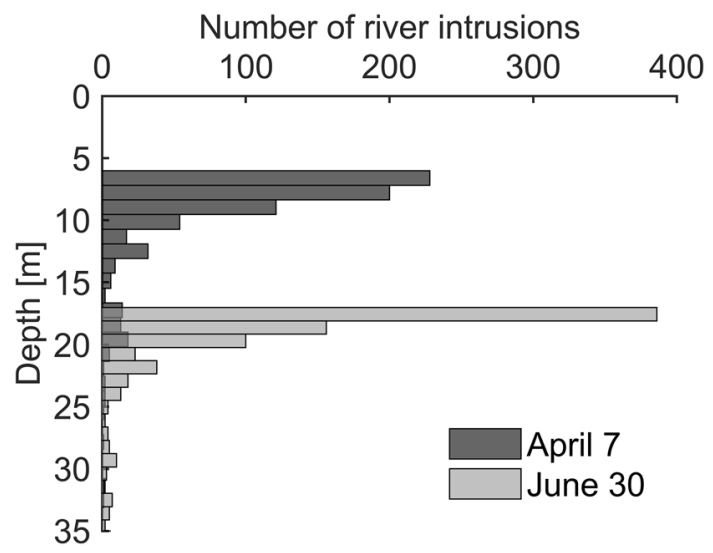

Fig. 7 Histogram of the depth distribution of Rhône intrusions into Lake Geneva for early April 2014 (black) and for end of June 2014 (grey). River data have a time interval of $10 \mathrm{~min}$ and are taken over 5 days before the profile measurements at SHL2 depth has to be compared to the Secchi depth. Secchi depths, monitored at SHL2 (Fig. 1) in spring 2014, were in the range of 5.8-6.2 m. In June 2014, they varied between 5.7 and $8.8 \mathrm{~m}$ and we conclude that the turbid water intrusion is too deep to be detected by remote sensing even if the top water layer is clear.

Although the river inflow intrudes below the optical depth of the lake water, particle detrainment of the plunging riverine water can lead to a marginal hypopycnal flow (e.g. overflow) sometimes visible at the lake surface (Fig. 4a, d). Yet, the absence of diffusive gradient between the source (Rhône River) and the front of the plume is not consistent with physical transport and mixing from a local source in both underflow and overflow cases. From a numerical particle tracking experiment, we show that the spatial extent of the bright feature for June 15, 2014 corresponds almost exactly to the path of particles coming from the Rhône River inlet area (Fig. 8) and travelling within the thermocline (at $\sim 15 \mathrm{~m}$ depth) within a week of the event. This suggests that the Rhône River input plays a major role in the process occurring around the north-eastern part of Lake Geneva and it allows us to comprehend its spatial extension.

\section{Calcium balance in the surface layer}

A milky blue coloration of the water is theoretically possible also in the case of some phytoplankton blooms like the coccolithophore Emiliania Huxleyi. However, these oceanic species do not occur in freshwater. There are freshwater phytoplankton species that scatter light effectively, like cyanobacteria, and can cause bright reflectance. However,

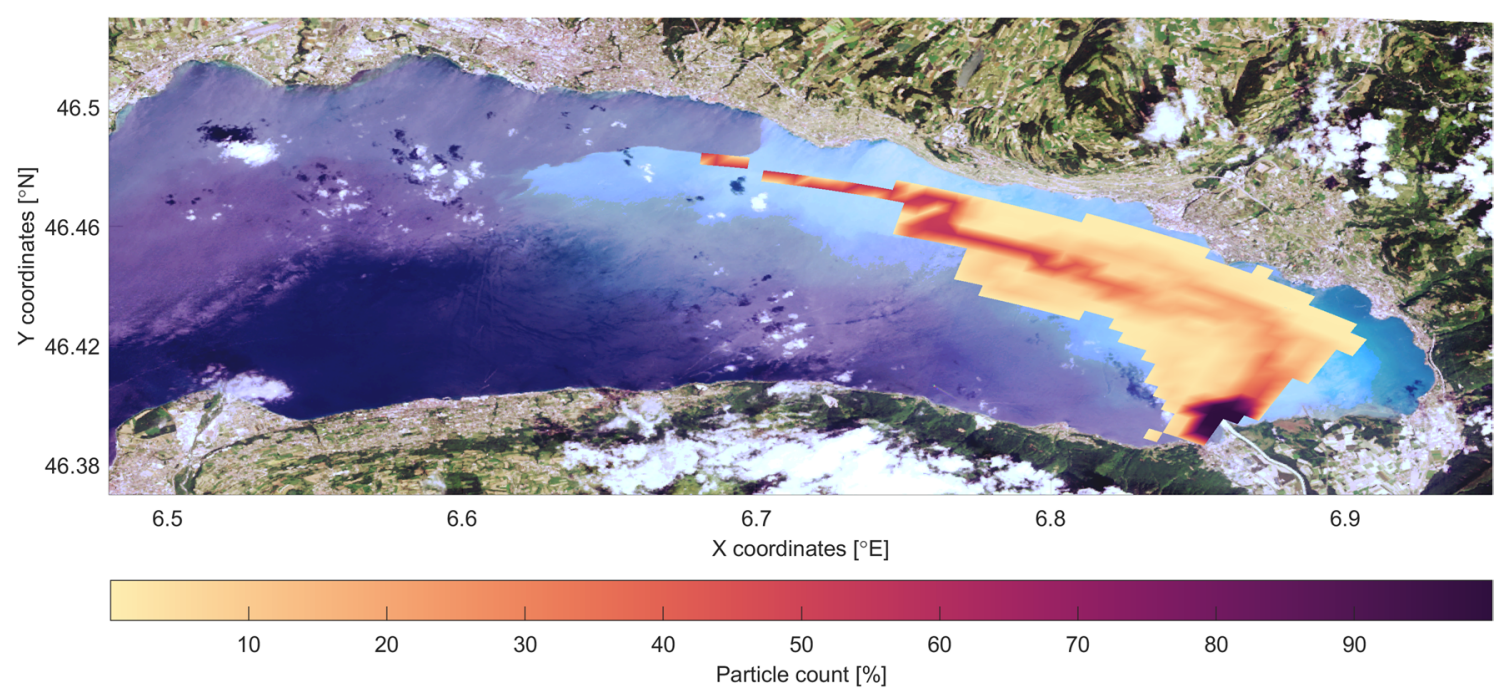

Fig. 8 The background of the figure corresponds to the Landsat- 8 image of Lake Geneva from June 15, 2014 (Fig. 4c). The overlaid plot (yellow-red) represent the percent of particles originating from the Rhône River inflow, passing by the corresponding element of the grid of the hydrodynamic model. One particle every 10 min was released at the Rhône River mouth (maximum spread of $500 \mathrm{~m}$ ) between June 8 and June 15, 2014 and advected into the lake using the average velocity field between 1 and $15 \mathrm{~m}$ depth 
high water reflectance from cyanobacterial blooms is associated also with elevated absorption at blue wavelengths (due to chlorophylls) making the water greenish. This was not observed in Lake Geneva. Thus, the only potential cause of this massive whiting of water is calcite precipitation. Therefore, we studied whether there were any changes in the $\mathrm{Ca}^{2+}$ concentration during the period of interest.

Measurements from the water column of Lake Geneva were available in 2014 from June 2 and 30, while the event occurred close to June 16 . In the top $20 \mathrm{~m}$, calcite was up to five-fold supersaturated on June 2 (Fig. 9, left panel, Eq. 2). Calcite supersaturation can persist up to very high values of $\Omega$ without precipitating for various reasons, e.g. prevention of the growth of initial nuclei by sorption of phosphate (Lotter et al. 1997; Niessen and Sturm 1987), but can be initiated by the introduction of additional nucleation seeds. It is most likely that the high fine particle load of the Rhône provided such active particulate surfaces that initiated calcite precipitation, even though the river water itself was slightly below saturation with respect to calcite $(\Omega=0.93)$. The concentrations of $\mathrm{Ca}^{2+}$ in the top $20 \mathrm{~m}$ of the water column decreased between June 2 and 30 (Fig. 9, right panel), indicating the removal of calcite. Integration of the $\mathrm{Ca}^{2+}$ removed from the top $20 \mathrm{~m}$ yields an event-specific areal precipitation of $44 \mathrm{~g}$ $\mathrm{Ca} \mathrm{m}^{-2}\left(1.1 \mathrm{~mol} \mathrm{~m}^{-2}\right)$.

This amount of Ca precipitation for individual whiting event is quite realistic. In the last 2 decades, annual $\mathrm{Ca}$ sedimentation in Lake Geneva averaged to $\sim 140 \mathrm{~g} \mathrm{Ca} \mathrm{m}^{-2}$ year ${ }^{-1}$ (Dominik et al. 1993) and $\sim 190 \mathrm{~g} \mathrm{Ca} \mathrm{m}^{-2}$ year $^{-1}$ (Graham et al. 2016), which covers a range consistent with Ca sedimentation of $\sim 170 \mathrm{~g} \mathrm{Ca} \mathrm{m}^{-2}$ year $^{-1}$ as determined for the two hard-water Lakes Lugano and Sempach (Ramisch et al. 1999). This comparison indicates that this individual whiting event was removing $\sim 1 / 4$ of an annual Ca deposition, which appears realistic in view that the Ca sedimentation was shown to scale with the organic matter production and sedimentation (Graham et al. 2016). This large amount of calcite precipitation also shows, that the net carbon removal into the sediment reaches several $10 \mathrm{~g} \mathrm{C} \mathrm{m}^{-2}$ year $^{-1}$, which is a major term in the carbon budget and exceeds the organic C deposition in those lakes (Loizeau et al. 2012; Schwefel et al. 2016).

\section{Rhône River inputs}

The wide public attention to this whiting event suggests that something extraordinary may have happened in Lake Geneva in summer 2014. Actually, this event is far from being unique. Monitoring data from 2011 to 2017 (Fig. 10) shows that the 2014 summer was quite typical. It is seen also in Fig. 6 that the phytoplankton dynamics was similar to what has been observed before (Nouchi et al. 2018). Similar decreases in $\mathrm{Ca}^{2+}$ concentrations occurred also during previous years and were most probably associated to similar calcite precipitation events that colour water turquoise. Most probably the 2014 event got more attention because it occurred near shore and affected harbours and beaches while potential offshore whiting may not be recognised. The duration of the whiting events (approximately 10 days in this study) and the frequency of monitoring (monthly to fortnightly in productive seasons) makes it highly possible that the whiting events were missed also by conventional monitoring. Combining Sentinel-2A and 2B with Landsat-8 allows now to obtain lake imagery with a frequency that will reliably allow monitoring blooms and whiting events.

\section{Conclusion}

This study shows that remote sensing is a powerful tool to understand different simultaneously occurring processes in lakes. Synergistic multi-platform remote sensing efficiently provided information regarding the spatial and temporal variability of whiting events in Lake Geneva. Specifically, we show that combining the spatial resolution of Landsat-8 and temporal coverage of MODIS can extend the information retrieved from remote observations. However, different processes (e.g. river plumes and calcite precipitation) may have
Fig. 9 Saturation index $\Omega$ at SHL2 for June 2, 2014 (left), and Ca precipitation (right) estimated over the month of June 2014 plotted as the difference in $\mathrm{Ca}^{2+}$ concentration between June 30 and June 2. The Ca depletion is restricted to the top $20 \mathrm{~m}$ with the maximum right at the surface. The integrated Ca precipitation for this event was $44 \mathrm{~g} \mathrm{~m}^{-2}$ in the top $20 \mathrm{~m}$; $\mathrm{dl}=$ dimensionless
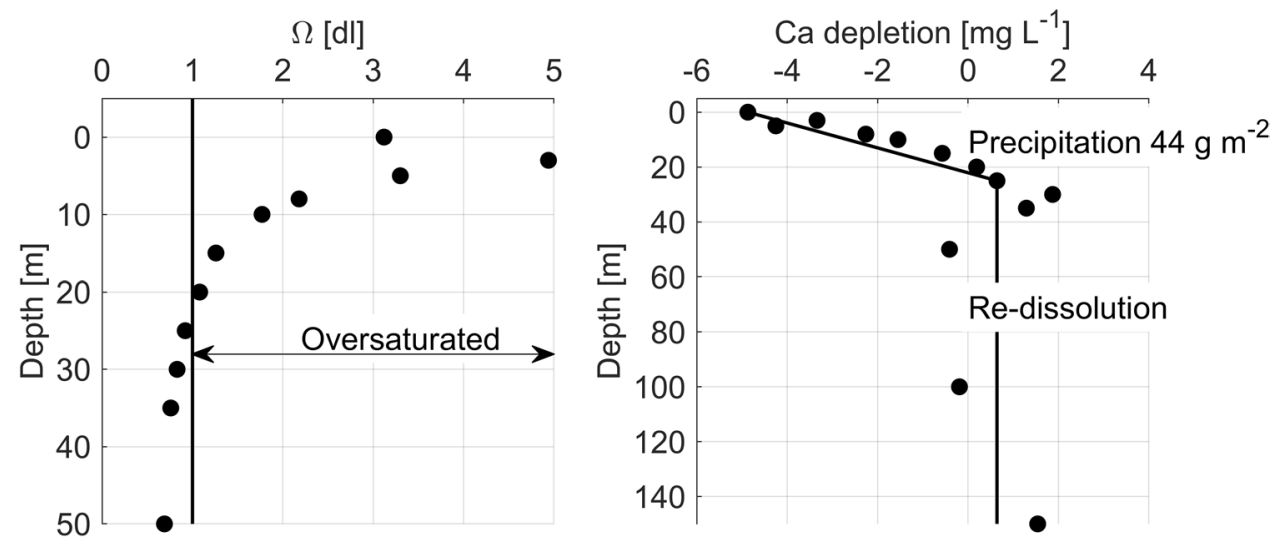
Fig. 10 Rhône physico-chemical parameters at PS from 2011 to $2017 ; \mathrm{dl}=$ no dimension
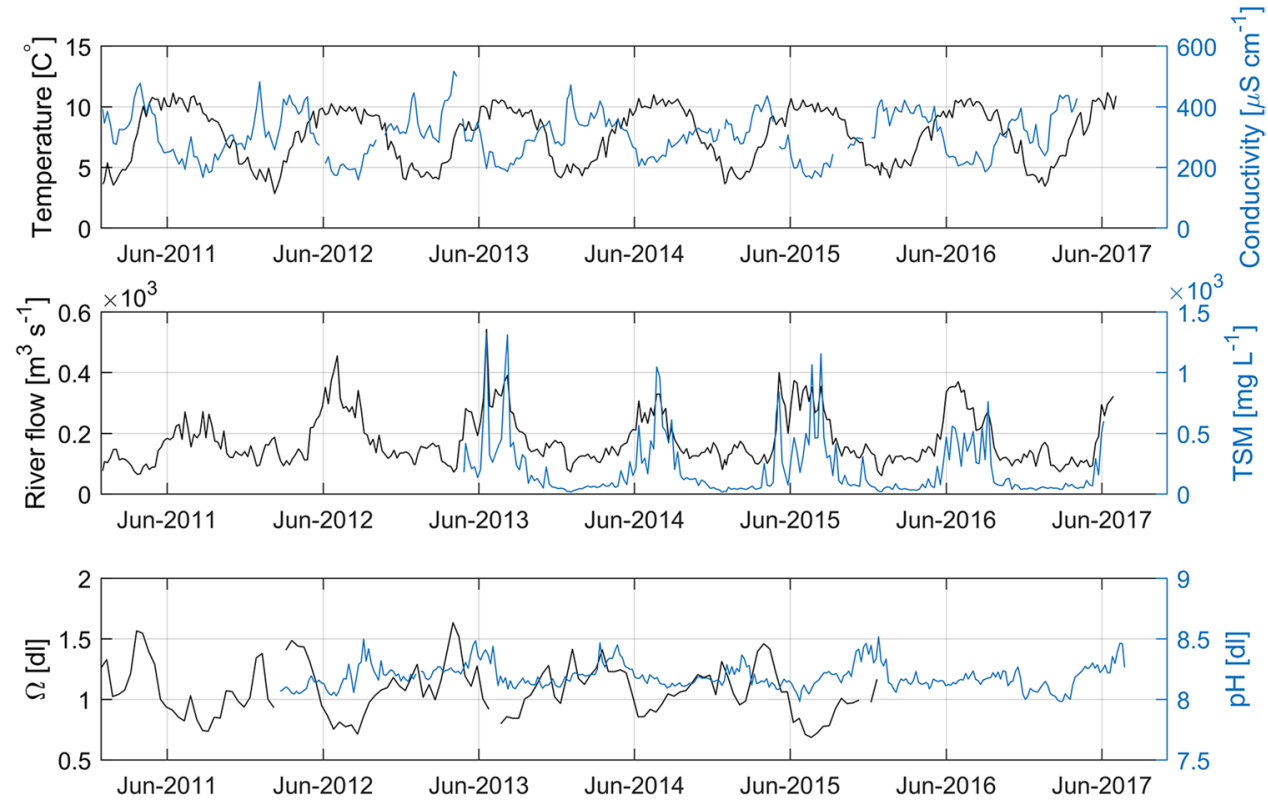

similar spectral signatures. In such cases, applying the same data analysis procedure may lead to erroneous interpretation of the remote sensing signals. Combining remote sensing data with additional local information (such as in-situ data, hydrodynamic and biogeochemical models, etc.) allows a much deeper understanding of processes which will remain inextricable by solely using remote sensing or in-situ measurements.

We show that the observed whiting event was triggered by the Rhône River entering the lake and the signature of the event, including its in-lake development, was mostly advected by the lake circulation. This study also indicates that whiting events may regularly occur in early summer in Lake Geneva. In the future, whiting, or other processes related to the interaction between riverine and lake water, have the potential to be identified in spatial and temporal extensions much easier by applying the proposed procedure.

Acknowledgements This work was supported by the Margaretha Kamprad Chair at EPFL and by the Fondation pour l'Etude des Eaux du Léman (FEEL) on Lake Geneva. Finally, we acknowledge Carole Lebreton for her kind support with the configuration of the MODIS processing chain and for Brockmann Consult for operating and providing access to the Calvalus cluster computer system. In-situ profiles at SHL2 were provided by the Commission International pour la Protection des Eaux du Leman (CIPEL), INRA CARRTEL Thonon les Bains, and the Information System of the SOERE OLA (http://si-ola.inra. fr) developed by the Eco-Informatique group of INRA. Finally, we acknowledge the Federal Office for the environment (FOEN) for providing National River Monitoring and Survey Programme (NADUF) dataset at PS available at https://www.bafu.admin.ch.

\section{References}

Anneville O, Pelletier JP (2000) Recovery of Lake Geneva from eutrophication: quantitative response of phytoplankton. Arch Hydrobiol 148:607-624

Anneville O, Ginot V, Angeli N (2002a) Restoration of Lake Geneva: expected versus observed responses of phytoplankton to decreases in phosphorus. Lakes Reserv Res Manag 7(2):67-80

Anneville O, Souissi S, Ibanez F, Ginot V, Druart JC, Angeli N (2002b) Temporal mapping of phytoplankton assemblages in Lake Geneva: annual and interannual changes in their patterns of succession. Limnol Oceanogr 47:1355-1366

Balch WM, Eppley RW, Abbott MR, Reid FMH (1989) Bias in satellite-derived pigment measurements due to coccolithophores and dinoflagellates. J Plankton Res 11:575-581. https://doi. org/10.1093/plankt/11.3.575

Blanc P, Pelletier JP, Moille JP (1993) Variabilité spatiale et temporelle des paramètres physico-chimiques et biologiques dans les eaux du Léman. Rapp Comm int prot eaux Léman contre pollut, campagne 1992:113-162, 162b-162p

Bouffard D, Lemmin U (2013) Kelvin waves in Lake Geneva. J Great Lakes Res 39:637-645. https://doi.org/10.1016/j. jglr.2013.09.005

Bouffard D, Kiefer I, Wüest A, Wunderle S, Odermatt D (2018) Are surface temperature and chlorophyll in a large deep lake related? An analysis based on satellite observations in synergy with hydrodynamic modelling and in-situ data. Remote Sens Environ 209:510-523. https://doi.org/10.1016/j.rse.2018.02.056

Brezonik P, Menken KD, Bauer M (2005) Landsat-based remote sensing of lake water quality characteristics, including chlorophyll and Colored Dissolved Organic Matter (CDOM). Lake Reserv Manag 21(4):373-382. https://doi.org/10.1080/07438 140509354442 
Bricaud A, Morel A (1986) Light attenuation and scattering by phytoplanktonic cells: a theoretical modeling. Appl Opt 25:571. https ://doi.org/10.1364/AO.25.000571

Brockmann C, Doerffer R, Peters M, Stelzer K, Embacher S, Ruescas A (2016) Evolution of the C2RCC neural network for Sentinel 2 and 3 for the retrieval of ocean colour products in normal and extreme optically complex waters. In: Ouwehand L (ed) Proceedings of the living planet symposium, 9-13 May 2016, Prague, Czech Republic, ESA-SP vol 740, pp 54. ISBN: 978-92-9221-305-3

Burkard P (1984) Hydrologie-Bilan hydrologique. In: Comm. int. protection des eaux du Léman, Lausanne: Le Léman Synthèse 1957-1982, CIPEL, Nyon, Switzerland, pp 43-48

Chen CT, Millero FJ (1986) Thermodynamic properties for natural waters covering only the limnological range. Limnol Oceanogr 31(3):657-662

CIPEL (2015) Rapports sur les études et recherches entreprises dans le bassin Lémanique, campagne 2014. Commission internationale pour la protection des eaux du Léman contre la pollution, CIPEL, Nyon Switzerland, pp 27-31

Doerffer R, Schiller H (2007) The MERIS Case 2 water algorithm. Int J Remote Sens 28:517-535. https://doi.org/10.1080/0143116060 0821127

Dominik J, Dulinski M, Span D, Hofmann A, Favarger PY, Vernet JP (1993) Transfert de matière et de radio-isotopes entre l'eau et les sediments dans le Léman Tech rep. Commission Internationale Pour la Protection des Eaux du Léman, CIPEL, Nyon, Switzerland

Finger D, Schmid M, Wüest A (2006) Effects of upstream hydropower operation on riverine particle transport and turbidity in downstream lakes. Water Resour Res 42(8):W08429. https://doi. org/10.1029/2005WR004751

Gallina N, Salmaso N, Morabito G, Beniston M (2013) Phytoplankton configuration in six deep lakes in the peri-Alpine region: are the key drivers related to eutrophication and climate? Aquat Ecol 47(2):177-193. https://doi.org/10.1007/s10452-013-9433-4

Giovanoli VF, Lambert A (1985) Die Einschichtung der Rhone im Genfersee: Ergebnisse von Strömungsmessungen im August 1983. Schweiz Z Hydrol 47:159-178

Graham ND, Bouffard D, Loizeau J-L (2016) The influence of bottom boundary layer hydrodynamics on sediment focusing in a contaminated bay. Environ Sci Pollut Res 23:25412-25426. https ://doi.org/10.1007/s11356-016-7715-9

Hauenstein W, Dracos T (1984) Investigation of plunging density currents generated by inflows in lakes. J Hydraul Res 22:157-179. https://doi.org/10.1080/00221688409499404

IOCCG (2000) Remote sensing of ocean colour in coastal, and other optically-complex, waters. In: Sathyendranath S (ed) Reports of the international ocean-colour coordinating group, no. 3. IOCCG. Darthmouth

Kallio K, Attila J, Härmä P, Koponen S, Pulliainen J, Hyytiäinen MJ, Pyhälahti T (2008) Landsat ETM + images in the estimation of seasonal lake water quality in boreal river basins. Environ Manage 42(3):511-522. https://doi.org/10.1007/s00267-008-9146-y

Kiefer I, Odermatt D, Anneville O, Wüest A, Bouffard D (2015) Application of remote sensing for the optimization of in-situ sampling for monitoring of phytoplankton abundance in a large lake. Sci Total Envir 527-528:493-506. https://doi.org/10.1016/j.scito tenv.2015.05.011

Kutser T (2012) The possibility of using the Landsat image archive for monitoring long time trends in coloured dissolved organic matter concentration in lake waters. Remote Sens Environ 123:334-338. https://doi.org/10.1016/j.rse.2012.04.004

Kutser T, Vahtmäe E, Martin G (2006) Assessing suitability of multispectral satellites for mapping benthic macroalgal cover in turbid coastal waters by means of model simulations. Estuar Coast Shelf Sci 67(3):521-529. https://doi.org/10.1016/j.ecss.2005.12.004
Kutser T, Metsamaa L, Dekker AG (2008) Influence of the vertical distribution of cyanobacteria in the water column on the remote sensing signal. Estuar Coast Shelf Sci 78(4):649-654. https://doi. org/10.1016/j.ecss.2008.02.024

Kutser T, Paavel B, Verpoorter C, Ligi M, Soomets T, Toming K, Casal $\mathrm{G}$ (2016) Remote sensing of black lakes and using $810 \mathrm{~nm}$ reflectance peak for retrieving water quality parameters of optically complex waters. Remote Sens 8(6):497. https://doi.org/10.3390/ rs8060497

Lambert A, Giovanoli F (1988) Records of riverborne turbidity currents and indications of slope failures in the Rhone delta of Lake Geneva. Limnol Oceanogr 33(3):458-468

Lee Z, Shang S, Qi L, Yan J, Lin G (2016) A semi-analytical scheme to estimate Secchi-disk depth from Landsat-8 measurements. Remote Sens Environ 177:101-106. https://doi.org/10.1016/j. rse.2016.02.033

Loizeau J-L, Dominik J (2000) Evolution of the Upper Rhone River discharge and suspended sediment load during the last 80 years and some implications for Lake Geneva. Aquat Sci 62:54-67. https://doi.org/10.1007/s000270050075

Loizeau J-L, Girardclos S, Dominik J (2012) Taux d'accumulation des sediments recents et bilan de la matière particulaire dans le Leman (Suisse-France). Arch Sci 65:81-92

Lotter AF, Sturm M, Teranes JL, Wehrli B (1997) Varve formation since 1885 and high-resolution varve analyses in hypertrophic Baldeggersee (Switzerland). Aquat Sci 59:304-325. https://doi. org/10.1007/BF02522361

Matthews MW (2011) A current review of empirical procedures of remote sensing in inland and near-coastal transitional waters. Int J Remote Sens 32:6855-6899

Niessen F, Sturm M (1987) The sediments of Lake Baldegg (Switzerland)-sedimentary environment and development of eutrophication for the last 100 year (in German, with English abstract). Arch Hydrobiol 108:365-383. https://doi.org/10.4319/ lo.2005.50.3.0914/pdf

Nouchi V, Odermatt D, Wüest A, Bouffard D (2018) Effects of nonuniform vertical constituent profiles on remote sensing reflectance of oligo- to mesotrophic lakes. Eur J Remote Sens 51:808-821. https://doi.org/10.1080/22797254.2018.1493360

Obst M, Wehrli B, Dittrich M (2009) $\mathrm{CaCO}_{3}$ nucleation by cyanobacteria: laboratory evidence for a passive, surface-induced mechanism. Geobiology 7(3):324-347. https://doi.org/10.111 1/j.1472-4669.2009.00200.x

Odermatt D, Giardino C, Heege T (2010) Chlorophyll retrieval with MERIS Case-2-Regional in perialpine lakes. Remote Sens Environ 114:607-617. https://doi.org/10.1016/j.rse.2009.10.016

Odermatt D, Gitelson A, Brando VE, Schaepman ME (2012) Review of constituent retrieval in optically deep and complex waters from satellite imagery. Remote Sens Environ 118:116-126

Pahlevan N, Lee Z, Wei J, Schaaf CB, Schott JR, Berk A (2014) Onorbit radiometric characterization of OLI (Landsat-8) for applications in aquatic remote sensing. Remote Sens Environ 154:272284. https://doi.org/10.1016/j.rse.2014.08.001

Palmer SCJ, Kutser T, Hunter PD (2015) Remote sensing of inland waters: challenges, progress and future directions. Remote Sens Environ 157:1-8. https://doi.org/10.1016/j.rse.2014.09.021

Pitarch J, Odermatt D, Kawka M, Wüest A (2014) Retrieval of vertical particle concentration profiles by optical remote sensing: a model study. Opt Express 22:A947-A959. https://doi.org/10.1364/ OE.22.00A947

Plée K, Pacton M, Ariztegui D (2010) Discriminating the role of photosynthetic and heterotrophic microbes triggering low-Mg calcite precipitation in freshwater biofilms (Lake Geneva, Switzerland). Geomicrobiol J 27(5):391-399. https://doi.org/10.1080/01490 450903451526 
Plummer LN, Busenberg E (1982) The solubilities of calcite, aragonite and vaterite in $\mathrm{CO}_{2} \mathrm{H}_{2} \mathrm{O}$ solutions between 0 and $90{ }^{\circ} \mathrm{C}$, and an evaluation of the aqueous model for the system $\mathrm{CaCO}_{3} \mathrm{CO}_{2} \mathrm{H}_{2} \mathrm{O}$. Geochim Cosmochim Acta 46(6):1011-1040. https://doi. org/10.1016/0016-7037(82)90056-4

Råman Vinnå L, Wüest A, Bouffard D (2017) Physical effects of thermal pollution in lakes. Water Resour Res 53(5):3968-3987. https ://doi.org/10.1002/2016WR019686

Råman Vinnå L, Wüest A, Zappa M, Fink G, Bouffard D (2018) Tributaries affect the thermal response of lakes to climate change. Hydrol Earth Syst Sci 22:31-51. https://doi.org/10.5194/ hess-2017-337

Ramisch F, Dittrich M, Mattenberger C, Wehrli B, Wüest A (1999) Calcite dissolution in two deep eutrophic lakes. Geochim Cosmochim Acta 63:3349-3356

Sastre V, Loizeau J-L, Greinert J, Naudts L, Arpagaus P, Anselmetti F, Wildi W (2010) Morphology and recent history of the Rhone River Delta in Lake Geneva (Switzerland). Swiss J Geosci 103:33-42. https://doi.org/10.1007/s00015-010-0006-4

Schwefel R, Gaudard A, Wüest A, Bouffard D (2016) Effects of climate change on deepwater oxygen and winter mixing in a deep lake (Lake Geneva): comparing observational findings and modeling. Water Resour Res 52(11):8811-8826. https://doi. org/10.1002/2016WR019194

Slonecker ET, Jones DK, Pellerin BA (2016) The new Landsat 8 potential for remote sensing of colored dissolved organic matter (CDOM). Mar Pollut Bull 107(2):518-527. https://doi. org/10.1016/j.marpolbul.2016.02.076

Soulignac F, Danis P-A, Bouffard D, Chanudet V, Dambrine E, Guénand Y, Harmel T, Ibelings BW, Trevisan D, Uittenbogaard R, Anneville O (2018) Using 3D modeling and remote sensing capabilities for a better understanding of spatio-temporal heterogeneities of phytoplankton abundance in large lakes. J Great Lakes Res 44(4):756-764

Spencer RJ, Eugster HP, Jones BF (1985) Geochemistry of great Salt Lake, Utah II: Pleistocene-Holocene evolution. Geochim Cosmochim Acta 49:739-747. https://doi.org/10.1016/00167037(85)90168-1
Spyrakos E, O'Donnell R, Hunter PD et al (2018) Optical types of inland and coastal waters. Limnol Oceanogr 63(2):846-870. https ://doi.org/10.1002/lno.10674

Strickland JDH, Parsons TR (1968) A practical handbook of seawater analysis. Bull Fish Res Board, Canada, p 167

Stumm W, Morgan JJ (1996) Aquatic chemistry: chemical equilibria and rates in natural waters, 3rd edn. Wiley Inter-science, New York (ISBN: 978-0-471-51185-4)

Vanhellemont Q, Ruddick K (2014) Turbid wakes associated with offshore wind turbines observed with Landsat 8. Remote Sens Environ 145:105-115. https://doi.org/10.1016/j.rse.2014.01.009

Vanhellemont Q, Ruddick K (2015) Advantages of high quality SWIR bands for ocean colour processing: examples from Landsat-8. Remote Sens Environ 161(5):89-106. https://doi.org/10.1016/j. rse.2015.02.007

Vanhellemont Q, Ruddick K (2016) Acolite for Sentinel-2: aquatic applications of MSI imagery. In: Proceedings of the ESA living planet symposium, Prague, Czech Republic, pp 9-13. http://odnat ure.naturalsciences.be/downloads/publications/2016_Vanhellemo nt_ESALP.pdf. Accessed 12 Dec 2017

Wells AJ, Illing LV (1964) Present-day precipitation of calcium carbonate in the Persian Gulf. Dev Sedimentol 1:429-435. https:// doi.org/10.1016/S0070-4571(08)70517-X

Xue K, Zhang Y, Duan H, Ma R, Loiselle S, Zhang M (2015) A remote sensing approach to estimate vertical profile classes of phytoplankton in a eutrophic lake. Remote Sens 7(11):14403-14427

Xue K, Zhang Y, Ma R, Duan H (2017) An approach to correct the effects of phytoplankton vertical nonuniform distribution on remote sensing reflectance of cyanobacterial bloom waters. Limnol Oceanogr Methods 15:302-319

Publisher's Note Springer Nature remains neutral with regard to jurisdictional claims in published maps and institutional affiliations. 